\title{
Manajemen Komunikasi Pemerintah Desa dalam Melaksanakan Forum Keamanan Terpadu (Kajian Pada Kelurahan Balekambang Jakarta Timur)
}

\author{
Yayu Sriwartini ${ }^{2}$ \\ Universitas Nasional,yayu_sriwartini@yahoo.com,
}

\begin{abstract}
ABSTRAK
Penelitian ini mengangkat permasalahan manajemen komunikasi dalam struktur pemerintahan kelurahan dalam membangun sumber daya manusia dan lingkungan yang berkualitas, terutama kaitannya dalam menciptakan keamanan, ketertiban lingkungan serta mengembangkan potensi warga agar dinamis dan produktif. Adapun tujuan penelitian adalah untuk memberikan gambaran yang detil dan komprehensif mengenai (1) perencanaan kegiatan komunikasi dan proses pengorganisasi dalam menjalankan Forum Keamanan Terpadu; (2) bentuk forum komunikasi dan evaluasi yang dibangun dalam melaksanakan Forum Keamanan Terpadu. Manajemen Komunikasi danTeori Likert Empat Sistem menjadi landasan dalam penelitian ini untuk menganalisis temuan di lapangan. Penelitian ini bersifat deskriptif dengan menggunakan paradigm interpretif. Adapun subyeknya adalah Pemerintahan Kelurahan Balekambang Jakarta Timur. Sementara objek kajiannya adalah tentang manajemen komunikasi dalam melaksanakan forum keamanan terpadu. Teknik yang digunakan dalam mengumpulkan data adalah wawancara dengan key informan, yakni Lurah Balekambang, sedangkan informan, adalah ketua Wanra, ketua FKDM, ketua POKDAR,ketua LMK dan Ketua Karang taruna. Dalam mengolah dan menganalisa data, peneliti melakukan beberapa tahapan. Dalam penelitian ini juga akan dilakukan uji keabsahan data. Jika dilihat dari perspektif teori likert dalam komunikasi organisasi, pimpinan Kelurahan Balekambang sangat adaptif terhadap situasi lingkungan setempat. Tentu saja persetujuan didirikannya Forum Keamanan Terpadu ini merupakan bagian dari upaya pimpinan mengakomodasi gagasan warga. Dalam pandangan teori ini, gaya kepemimpinan Lurah Balekambang lebih menunjukkan gaya konsultatif dan partisipatif.
\end{abstract}

Key words: Manajemen Komunikasi, Pemerintahan Kelurahan, Forum Keamanan.

\section{ABSTRACT}

This research examines the problem of communication management in the village government structure, in building quality human and environmental resources, especially in relation to creating security, environmental order, and developing the potential of citizens to be dynamic and productive. The purpose of the study is to provide a detailed and comprehensive description of (1) planning communication activities and the organizing process in running the Integrated Security Forum; (2) the form of communication and evaluation forums built in implementing the Integrated Security Forum.The cornerstone of the theory in this research is Communication Management and Four-System Likert Theory to analyze findings in the field. This research is

\footnotetext{
${ }^{2}$ Dosen tetap Prodi Ilmu Komunikasi Universitas Nasional, Jakarta.
} 


\section{PERSESPSSI}

Volume 1 Nomor 1. Juli - Desember 2018

descriptive by using the interpretive paradigm. The subject is the Government of the Village of Balekambang, East Jakarta.The object of the study is about communication management in implementing integrated security forums. The technique used in collecting data was interviews with key informants, namely the Village Head of Balekambang, while the informants were the chairman of Wanra, the head of the FKDM, the chairman of the POKDAR, the chairman of the LMK and the Chairperson of the Karang Taruna.In processing and analyzing data, researchers conducted several stages. In this study also tested the validity of the data. If viewed from the perspective of the Likert theory in organizational communication, the leadership of the Balekambang Village is very adaptive to the local environmental situation. Of course the approval of the establishment of the Integrated Security Forum is part of the leadership efforts to accommodate citizen ideas. In view of this theory, the leadership style of the Balekambang urban village shows more consultative and participatory styles.

Key words: Communication Management, Village Government, Security Forum.

\section{PENDAHULUAN}

Dalam kehidupan sehari-hari setiap warga di lingkungan masyarakat manapun tentunya menginginkan situasi dan kondisi yang aman serta nyaman. Namun pada kenyataannya permasalahan selalu saja muncul, mulai dari hal yang sederhana sampai masalah pelik dan mulai dari persoalan pribadi hingga permasalahan sosial. Tentu saja beragam permasalahan tersebut akan menggangu ketertiban dan kondusivitas lingkungan jika tidak segera diatasi.

Manusia dan lingkungan mempunyai timbal balik. Manusia sangat membutuhkan suatu lingkungan yang baik, aman dan kondusif. Karena dengan lingkungan tersebut, manusia dapat berkembang dengan baik pula. Sebaliknya, lingkungan juga membutuhkan manusia. Dengan manusia yang baik, maka baik pula lingkungannya. Menjaga lingkungan sekitar adalah kewajiban dari semua warga, namun kehadiran pemimpin pun mutlak diperlukan. Di lingkungan rukun tetangga, maka harus ada seorang RT yang bisa mengayomi, melindungi dan mengontrol warganya, begitu juga seterusnya di lingkungan warga ada RW, di lingkup kelurahan ada Lurah sampai pada presiden yang memimpin negeri ini.

Kelurahan merupakan wilayah gabungan dari beberapa Rukun Warga (RW). Pemerintahan di tingkat desa dan kelurahan merupakan unsur pemerintahan yang berhubungan langsung dengan masyarakat. Dalam menjalankan semua perencanaan pembangunan di kelurahan, terdapat Dewan Kelurahan (Dekel). Dewan Kelurahan inilah yanga berfungsi sebagai pemberi masukan kepada lurah tentang rencana pembangunan di wilayahnya. Ada enam (6) tugas yang harus diemban oleh lurah sebagai pemimpin organisasi sesuai dengan Peraturan Pemerintah Republik Indonesia Nomor 73 Tahun 2005 pasal 5 tentang kelurahan, yakni: 1) Pelaksanaan kegiatan pemerintahan Kelurahan, 2) Pemberdayaan 


\section{PESRSESI}

masyarakat, 3) Pelayanan masyarakat, 4) Penyelenggaraan ketentraman dan ketertiban hukum, 5) Pemeliharaan prasarana dan fasilitas pelayanan umum, 6) Pembinaan lembaga kemasyarakatan.

Lurah sebagai pemimpin formal yang langsung berhadapan dengan masyarakat, melaksanakan teknis administrasi Pemerintahan dan tugas pembangunan di Kelurahan. Maka dari itu kemampuan seorang lurah dalam memimpin Kelurahan sangat diperlukan guna menggali dan mengembangkan potensi serta memberdayakan masyarakatnya sehingga dengan demikian diharapkan agar pembangunan yang dikehendaki oleh pemerintah dan diperlukan oleh masyarakat dapat tercapai dengan baik.

Pembangunan suatu wilayah tidak hanya berbicara masalah fasilitas sosial (fasos) dan fasilitasi umum (fasum) secara fisik saja, tetapi juga bagaimana membangun kesadaran masyarakat untuk mencipatkan harmonisasi, saling tolong menolong, serta menjaga ketertiban dan keamanan untuk mewujudkan lingkungan yang bersih dan nyaman. Di Jakarta yang identik dengan kota besar metropolitan dengan beragam suka bangsa serta agama serta bermacam profesi, sangat lekat sebutan kota yang sudah maju, dan memiliki prestise tersendiri.

Namun kenyataannya tidak semua penduduk kota Jakarta memiliki kehidupan yang mewah, layak dan nyaman. Keberlimpahan penduduk luar kota ke Jakarta menjadikan kota dengan 267 desa ini sangat padat dan memiliki beragam permasalahan sosial, salah satunya masalah kriminalitas, ketertiban dan keamanan, di antaranya Terpadat penduduk pertama di Indonesia dengan jumlah penduduk 9.992.842 jiwa (www.detik.com), Kota termacet pertama di Indonesia pada tahun 2017 (properti.kompas.com/2018), Kota dgn wilayah paling banyak banjir di tahun 2017 (15 Kec)/news.detik.com, Kota dgn tingkat sex bebas tertinggi kedua tahun 2017 (www.inionline.id), Kejahatan di Jakarta terjadi per 15 menit ( www.viva..co.id), Jakarta Barat \& Timur: wilayah tawuran antar pelajar tertinggi 2016-2017 (kriminologi.id/maret 2018), Jakarta Timur: wilayah tawuran antar warga tertinggi sejak 2015 (kriminologi.id/maret 2018).

Situasi dan kondisi tersebut merupakan tantangan bagi kepala daerah untuk membasminya melalui pembentukan perangkat pengamanan desa yang terpadu. Tentu tidak semua wilayah sudah memiliki perangkat tersebut. Di Jakarta sendiri baru ada satu kelurahan yang sudah memiliki "infrastruktur" keamanan dan ketertiban yang terpadu, yakni Kelurahan Balekambang, Kecamatan Kramat Jati, Jakarta Timur. Kelurahan ini berbatasan dengan Kelurahan Batuampar di sebelah utara, Kelurahan Cililitan di sebelah barat, Kelurahan Kampung Gedong di sebelah timur dan Kelurahan Pasar Minggu di sebelah selatan

Sebagaimana dipaparkan sebelumnya bahwa pembangunan lingkungan warga tidak hanya sebatas pada bangunan fisiknya saja, tetapi juga SDM dan situasi serta kondisinya. Sudah jelas pembangunan fisik terlihat pada kelengkapan serta kerapihan fasilitas-faslitias umum dan sosial. Lalu pengembangan 


\section{PERSESPSI}

sumber daya manusia terlihat pada peningkatan kualitas dan kapasitasi diri warga yang dapat diwujudkan melalui berbagai kegiatan produktif dan konstruktif. Sedangkan penciptaan lingkungan yang aman, nyaman dan tertib dapat terlihat dari bebasnya lingkungan tersebut dari berbagai tindakan kriminal atau kegiatan-kegiatan warga yang meresahkan serta merugikan warga. Dalam rangka mewujudkan semua itu, di Kelurahan Balekambang sudah dibentuk Forum Keamanan Terpadu yang merupakan pelopor dan pilot project di Wilayah DKI Jakarta. Oleh karena itu, dalam penelitian ini permasalahan yang dirumuskan adalah Bagaimana Manajemen Komunikasi Pemerintah Desa dalam Melaksanakan Forum Keamanan Terpadu (Kajian Pada Kelurahan Balekambang Jakarta Timur)?

Penelitian ini mengangkat permasalahan manajemen komunikasi dalam struktur pemerintahan dalam membangun sumber daya manusia dan lingkungan yang berkualitas, terutama kaitannya dalam menciptakan keamanan, ketertiban lingkungan serta mengembangkan potensi warga agar dinamis dan produktif.

Adapun tujuan penelitian ini adalah untuk memberikan gambaran yang detil dan komprehensif mengenai hal-hal berikut ini:

1. Perencanaan kegiatan komunikasi Pemerintah Kelurahan Balekambang dalam menjalankan Forum Keamanan Terpadu.

2. Proses pengorganisasi dalam menjalankan Forum Keamanan Terpadu

3. Bentuk forum komunikasi dan evaluasi yang dibangun dalam melaksanakan Forum Keamanan Terpadu

\section{KAJIAN LITERATUR}

Sebagaimana dikutip Abidin (2015), manajemen menurut Harold Koontz dan Cyril O’Donnel adalah usaha mencapai tujuan tertentu melalui kegiatan oranglain. Pada prinsipnya manajemen merupakan alat untuk mencapai tujuan yang diinginkan oleh lembaga/organisasi bersangkutan. Andrew F. Sikula (Abidin, 2015) dan juga Soedarsono (2009) menjelaskan bahwa manajemen pada umumnya dikaitkan dengan aktivitas-aktivitas berikut ini yang dilakukan oleh setiap organisasi dengan tujuan untuk mengoordinasikan berbagai sumber daya yang dimiliki oleh perusahaan sehingga akan menghasilkan suatu produk atau jasa secara efisien:

a. Perencanaan. Perencanaan dilakukan sebelum kegiatan dilaksanakan dengan mempertimbangkan beberapa unsur seperti komunikator, pesan, media, khalayak dan efek.

b. Pengorganisasian. Yakni pengelompokan kegiatan kerja yang konkret dan tegas sesuai dengan lingkup pekerjaan dan pembagian tugas.

c. Pelaksanaan. Adalah membangkitkan dan mendorong semua personel organisasi agar berusaha untuk mencapai tujuan dengan ikhlas serta serasi dengan perencanaan dan usaha pengorganisasian dari pihak pimpinan. 


\section{PERSERESSI}

d. Pengawasan. Adalah proses penetapan ukuran kinerja dan pengambilan tindakan untuk mendukung tercapainya tujuan organisasi. Tujuan pengawasan adalah menghindari penyelewegan atau penyimpangan atas tujuan yang hendak dicapai.

Manajemen sangat penting dalam komunikasi, diantaranya komunikasi menentukan kualitas manajemen dan kepemimpinan. Sebaliknya, komunikasi pun memiliki fungsi dan tujuan dalam manajemen. Setidaknya ada empat (4) menurut Stephen P. Robbins (2007) yakni sebagai kendali, motivasi, pengungkapan emosional dan informasi.

\section{Sistem Manajemen Komunikasi Organisasi}

Komunikasi dalam organisasi adalah komunikasi yang dilakukan oleh pimpinan, baik dengan para karyawan maupun dengan khalayak yang ada kaitannya dengan organisasi, dalam rangka pembinaan kerja sama yang serasi untuk mencapai tujuan dan sasaran organisasi (Abidin, 2015). Dalam melakukan komunikasi organisasi,Tubbs dan Moss (2005) menguraikan tiga model dalam komunikasi, yakni komunikasi linier, komunikasi interaksional dan komunikasi transaksional. Menurut Face dan Paules (2000) dimensi komunikasi teridiri atas:

1) Komunikasi Internal. Yakni proses penyampaian pesan antara anggota organisasi yang terjadi untuk kepentingan organisasi. Sebagaimana dikutip dari Muhammad (2005)\& Abdullah (2008) Komunikasi internal dibedakan menjadi:

a) Komunikasi vertikal, yaitu komunikasi dari atas ke bawah dan dari bawah ke atas. Komunikasi dari pimpinan kepada bawahan dan dari bawahan kepada pimpinan. Dalam komunikasi vertikal, pimpinan memberikan instruksi, petunjuk dan informasi kepada bawahannya. Sedangkan bawahan memberikan laporan, saran dan pengaduan

b) Komunikasi horizontal atau lateral, yaitu komunikasi antara sesama. Pesan dalam komunikasi ini mengalir di bagian yang sama di dalam organisasi atau mengalir antarbagian. Komunikasi lateral ini memperlancar pertukaran pengetahuan, pengalaman, metode dan masalah. Hal ini membantu organisasi untuk menghindari beberapa masalah dan memecahkan hal lainnya serta membangun semangat kerja dan kepuasan kerja.

2) Komunikasi eksternal, yakni komunikasi antara pimpinan organisasi dengan khalayak di luar organisasi. Pada organisasi besar, komunikasi ini lebih banyak dilakukan oleh kepala hubungan masyarakat daripada pimpinan. Komunikasi eksternal terdiri atas jalur secara timbal balik, yaitu:

a) Komunikasi dari organiasi kepada khalayak. Komunikasi ini umumnya bersifat informatif sehingga khalayak merasa memiliki keterlibatan, setidaknya ada hubungan batin

b) Komunikasi dari khalayak kepada organisasi. Komunikasi ini merupakan umpan balik sebagai efek dari kegiatan dan komunikasi yang dilakukan oleh organisasi.

Sedangkan Gaya Komunikasi menurut Tubbs dan Moss (2005) mengemukakan ada enam gaya komunikasi dalam organisasi, antara lain:

1) The Controlling Style

Adalah gaya komunikasi yang bersifat mengendalikan. Ditandai dengan adanya satu kehendak atau tujuan untuk membatasi, memaksa dan mengatur perilaku, pikiran dan tanggapan oranglain. Pihakpihak yang menggunakan gaya ini lebih memusatkan perhatian kepada pengiriman pesan dibandingkan dengan upaya untuk berharap pesan. Mereka tidak mempunyai rasa ketertarikan dan perhatian untuk berbagi pesan dan umpan balik, kecuali jika umpan balik digunakan untuk kepentingan pribadinya. 


\section{PESRSESI}

\section{2) The Equalitarian Style}

Dalam gaya komunikasi ini, tindak komunikasi dilakukan secara terbuka. Artinya, setiap anggota organisasi dapat mengungkapkan gagasan ataupun pendapat dalam suasana yang santai dan informal. Suasana seperti ini memungkinkan setiap anggota organisasi mencapai kesepakatan dan pengertian bersama.

3) The Structuring Style

Gaya ini memanfaatkan pesan-pesan verbal secara tertulis ataupun lisan untuk memantapkan perintah yang harus dilaksanakan, penjadwalan tugas dan pekerjaan, serta struktur organisasi

4) The Dynamic Style

Gaya yang dinamis ini memiliki kencenderungan agresif karena pengirim pesan atau sender memahami bahwa lingkungan pekerjaannya berorientasi kepada tindakan. Tujuan utama gaya ini adalah menstimulasi atau merangsang pekerja/karyawan untuk bekerja dengan lebih cepat dan lebih baik.

5) The Relinguishing Style

Gaya ini mencerminkan kesediaan untuk menerima saran, pendapat ataupun gagasan oranglain daripada keinginan untuk memberikan perintah meskipun pengirim pesan mempunyai hak untuk memberikan perintah dan mengontrol oranglain.

6) The Withdrawal Style

Akibat yang muncul jika gaya ini digunakan adalah melemahnya tindak komunikasi. Artinya, tidak ada keinginan dari orang-orang yang menggunakan gaya ini untuk berkomunikasi dengan orang lain karena ada beberapa persoalan ataupun kesulitan yang dihadapi oleh orang-orang tersebut.

\section{Komunikasi Pemerintahan}

Komunikasi pemerintahan erat kaitannya dengan komunikasi organisasi dan komunikasi politik.

Hal ini dikarenakan ketika wilayah organisasi dan politik, pasti bersinggungan dengan pemerintahaan.

Dalam komunikasi pemerintahaan, terdapat dua tipe saluran komunikasi, yakni saluran komunikasi intern yang berkaitan dengan birokratik internal, fungsinya untuk memudahkan komunikasi di dalam internal publik pemerintahan dan saluran komunikasi ekternal, sebagai media komunikasi pemerintah dengan publiknya.

Adapun fungsi komunikasi dalam organisasi pemerintahan menurut Sendjaja (Abidin, 2016)dan Abdullah (2008) adalah:

\section{Fungsi Informatif}

Organisasi, termasuk organisasi pemerintahan dapat dipandang sebagai sistem pemrosesan informasi. Maksudnya, seluruh anggota dalam organisasi pemerintahan berharap dapat memperoleh informasi yang lebih baik, lebih banyak dan tepat waktu.

2. Fungsi Regulatif

Fungsi ini berkaitan dengan peraturan yang berlaku dalam suatu organisasi. Ada dua hal yang berpengaruh terhadap fungsi regulatif, yakni:

a. Berkaitan dengan orang-orang yang berada dalam tataran manajemen, yaitu mereka yang memiliki kewenangan untuk mengendalikan semua informasi yang disampaikan. Selain itum mereka bertugas memberi perintah atau instruksi agar perintah-perintahnya dilaksanakan sebagaimana mestinya.

b. Berkaitan dengan pesan. Pesan-pesan regulatif pada dasarnya berorientasi pada kerja. Artinya, bawahan membutuhkan kepastia perauturan tentang pekerjaan yang boleh dan tidak boleh untuk dilaksanakan. 


\section{PERSERESSI}

3. Fungsi Persuasif

Dalam mengatur suatu organisasi, termasuk organisasi pemerintahan, kekuasaan dan kewenangan tidak akan selalu membawa hasil sesuai dengan yang diharapkan.Kenyataan ini menyebabkan banyak pimpinan yang lebih menyukai untuk memersuasi bawahannya daripada memberi perintah.

4. Fungsi Integratif

Setiap organisasi akan berusaha menyediakan saluran yang memungkinkan karyawan dapat melaksanakan tugas dan pekerjaan dengan baik. Saluran komunikasi yang dapat mewujudkan hal tersebut adalah:

a. Saluran komunikasi formal seprti penerbitan khusus dalam organisasi dan laporan kemajuan organisasi

b. Saluran komunikasi informal, seperti perbincangan antar pribadi selama masa istirahat atau yang lainnya.

\section{Teori Likert}

Salah satu teori komunikasi kepemimpinan yang populer dan banyak diterapkan adalah teori Likert 4 Sitem atau 4 Gaya komunikasi kepemimpinan (Robbins \& Judge; 2007). Teori ini adalah teori sistem manajerial yang didasarkan oleh beberapa variabel penting yang berhubungan dengan manajerial seperti kepemimpinan, motivasi, komunikasi, interaksi, pengambilan keputusan, penentuan tujuan, pengendalian dan kinerja. Teori komunikasi kepemimpinan ini banyak digunakan untuk menganalisis pengaruh gaya komunikasi kepemimpinan terhadap perubahan kinerja dari pegawai atau bawahannya. Dalam teori Likert, komunikasi kepemimpinan dibedakan oleh 4 hal berikut:

\section{Gaya Penguasa Mutlak atau Authoritarian}

Dalam jenis sistem 1 Likert ini, pemimpin dideskripsikan memiliki sifat yang otoriter, berfokus pada tugas semata dan sangat terstruktur. Bagi pemimpin jenis ini, hubungan interpersonal antar pemimpin dan bawahan atau antar bawahan dianggap tidak penting dan tidak mempengaruhi kinerja dari pegawai. Pemimpin di tipe 1 ini tidak akan memberikan kepercayaan yang besar kepada bawahannya. Pemimpin ini juga tidak akan melibatnya pegawai lain dalam mengambil keputusan. Bagi pegawai, mereka akan merasa takut dan selalu terintimidasi dalam melakukan kerja. Komunikasi kepemimpinan yang terjadi dalam sistem 1 ini hanya terjadi satu arah yakni komunikasi dari atasan ke bawahan. Komunikasi jenis ini berdasarkan pada struktur organisasi dan kepemimpinan.

\section{Gaya Penguasa Semi Mutlak atau Benevolent Authoritative}

Pemimpin dengan gaya kepemimpinan seperti ini masih memiliki sifat otoritarian namun sudah mulai terbuka dan memberikan kepercayaan pada bawahannya. Dalam sistem 2 ini, pemimpin memiliki sifat task oriented namun menjalankan fungsi controlling untuk mengawasi kinerja pegawainya. Gaya kepemimpinan ini juga sering disebut sebagai sistem controlling. Di sistem ini, bawahan sudah diberikan 


\section{PESRERES}

kepercayaan dan ruang untuk memberikan pendapat dalam proses pengambilan keputusan. Pemimpin sudah memberikan kesempatan untuk terjadinya komunikasi dari bawahan ke atasan, meskipun mayoritas komunikasi yang terjadi dilakukan dari atasan ke bawahan. Komunikasi kepemimpinan yang berlangsung pada sistem jenis ini juga masih terjadi dalam suasana formal sesuai dengan jabatan ataupun struktur organisasi

\section{Gaya Pemimpin Penasihat atau Consultative}

Pemimpin pada sistem 3 ini lebih bersifat terbuka dan sudah memberikan kepercayaan lebih kepada bawahannya. Pemimpin tetap melakukan fungsi controlling namun dengan proses negoisasi dan kolaborasi. Dalam sistem ini, bawahan memiliki hak mengemukakan pendapat dalam pengambilan keputusan, terutama keputusan yang langsung berhubungan dengan tugas yang dikerjakan. Disini, komunikasi yang terjadi sudah dua arah yakni dari atasan ke bawahan dan sebaliknya. Interaksi antar pribadi sudah lebih sering dibandingkan dengan sistem 1 dan 2.

\section{Gaya Kepemimpinan Partisipatif}

Pemimpin dalam sistem 4 ini berkeyakinan bahwa organisasi akan berjalan lebih baik dengan adanya partisipasi aktif dari pegawainya. Disini pemimpin sudah memiliki kepercayaan dan keyakinan terhadap pegawainya. Pemimpin memberikan kepercayaan kepada bawahannya untuk bisa mengambil keputusan. Komunikasi yang terjadi pun lebih cair dengan alur atasan ke bawahan, bawahan ke atasan maupun bawahan ke bawahan. Pemimpin juga memberikan motivasi kepada pegawainya dengan cara memberikan ruang bagi mereka untuk berpartisipasi aktif dalam mewujudkan target organisasi. Proses komunikasi dan pertukaran ide berlangsung dengan terbuka dari atasan ke bawahan maupun sebaliknya

\section{METODE PENELITIAN}

Penelitian ini bersifat deskriptif dengan menggunakan paradigm interpretif yang bertujuan untuk membangun dan mengonstruksi sesuatu kehidupan sosial berdasarkan setting alamiah (Newman, 2003) \& Cresswell (1994). Pendekatannya adalah kualitatif yang dikemukakan Menurut Bogdan dan Taylor (Basrowi \& Sukidin, 2002) sebagai penelitian yang menghasilkan data deskriptif berupa ucapan, tulisan dan perilaku orang-orang yang diamati, sehingga peneliti dapat mengenali subjek dan merasakan apa yang mereka alami dalam kehidupan sehari-hari, yang mementingkan proses (bagaimana sesuatu terjadi) daripada produk hasilnya. Makna dalam penelitian ini adalah berkaitan dengan bagaimana persepsi dan pengalaman orang orang yang ada sehingga muncul saling memahami bagaimana orang memaknai 


\section{PERSESPSI}

Volume 1 Nomor 1. Juli - Desember 2018

kehidupan, dalam hal ini peneliti adalah sebagai instrument dan menggunakan interpretasi ideographic dalam setting natural.

Subyek dalam penelitian adalah Pemerintahan Kelurahan Balekambang Jakarta Timur. Objek kajiannya adalah tentang manajemen komunikasi dalam melaksanakan forum keamanan terpadu. Dalam mencari data, teknik digunakan dengan melakukan wawancara mendalam kepada (1) key informan, yakni Lurah Balekambang, Hj. Mintarsih, SE; (2) informan, adalah ketua Forum Keamanan Terpadu (FKT), Rodik (3) Ketua Babinsa Dalam mengolah dan menganalisa data, peneliti melakukan beberapa tahapan, sebagaimana yang dianjurkan oleh W. Laurence Newman (Basrowi \& Sukidin, 2002), di antaranya melakukan reduksi terhadap data yang diperoleh di lapangan, yang dilanjutkan dengan proses kategorisasi dan pengkodean terhadap data-data yang dianggap sama. Lalu penyajian data dalam bentuk narasi dan menganalisanya. Dalam penelitian ini juga akan dilakukan uji keabsahan data. Menurut Guba \& Lincoln (1994), data penelitian dikatakan absah bila data (1) dapat dipercaya (trustworthiness) yakni sejauhmana data penelitian memiliki kriteria kredibel, transferability, dependability dan confirmability dan (2) otentik/asli (authenticity)(Bryman, 2008). Beberapa langkah yang akan dilakukan peneliti dalam uji keabsahan data adalah:

Pertama, uji kredibilitas data dengan (a) turun langsung ke lapangan untuk memperoleh data dari key informan maupun informan (b) Menggunakan lebih dari dua narasumber untuk memperoleh data secara tepat dan tidak subjektif (3) penulis berupaya melakukan konfirmatori data pada narasumber (4) Memperpanjang masa pengamatan memungkinkan peningkatan derajat kepercayaan data yang dikumpulkan, bisa mempelajari kebudayaan dan dapat menguji informasi dari responden, dan untuk membangun kepercayaan para responden terhadap peneliti dan juga kepercayaan diri peneliti sendiri; Kedua uji trasferability dengan menyajikan data secara detil, sistematis dan komprehensif; Ketiga uji dependability dengan melakukan diskusi dengan teman sejawat yang diharapkan dapat mengaudit proses penelitian yang dilakukan dan member masukan. Selain itu untuk memperkuat keotentikan data, tentunya peneliti akan memperhatikan nilai-nilai kejujuran dan keterbukaan.

\section{PEMBAHASAN}

\section{A. Manajemen Komunikasi Pemerintah Desa (Kelurahan) Balekambang dalam}

\section{Melaksanakan Forum Keamanan Terpadu}

\section{Perencanaan pimpinan desa (Lurah dan Aparatnya) dalam melaksanakan Forum Keamanan} Terpadu.

Perencanaan dilakukan sebelum kegiatan dilaksanakan dengan mempertimbangkan beberapa unsur seperti komunikator, pesan, media, khalayak dan efek. Dalam proses perencanaan, awalnya Forum 


\section{PERSERES}

Keamanan Terpadu (FKT) diusulkan oleh Bhabinkamtibmas (Bhayangkara Pembina Keamanan dan Ketertiban Masyarakat) pada 2016. Hal itu didasari keinginan kuat dari warga untuk membuat semacam wadah yang menangani keamanan dan ketertiban di lingkungan Balekambang. Menurut Ketua FKT (Rfk) pada saat itu di lingkungan Balekambang seringkali terjadi gesekan antar pemuda serta tawuran dengan warga di luar Balekambang. Saat itu elemen masyarakat yang ada seperti RW, FKDM (Forum Kewaspadaan Dini Masyarakat), LMK (Lembaga Musyawarah Kelurahan) bergerak sendiri-sendiri. Tidak bisa sinkron dan tidak bisa bersinergi. Tetapi pelaksanaan penertiban oleh masing-masing lembaga tersebut dirasa kurang efektif. Selain itu terkesan memperlihatkan tidak adanya sinkronisasi dan kerjasama yang baik di antara lembaga sosial yang ada.

"Oleh karena itu saya sebagai warga biasa berpikir kenapa tidak dibuat sebuah lembaga yang mengintegrasikan seluruh kekuatan komponen saja. Karena hal itu akan lebih memudahkan dan justru membuat warga menjadi kompak serta memiliki tanggungjawab bersama, Selain itu UUD pasal 30 ayat 1 pun berbunyi bahwa setiap warga negera berhak ikutserta dalam upaya pertahanan negara, karena itu mengamalkan dan mengaplikasikannya di lingkungan ini adalah mensinergikan berbagai elemen keamanan di masyarakat," Ujar Rfk yang juga anggota anggota Bhabinkamtibmas Balekambang.

Ide atau gagasan tersebut kemudian disampaikan kepada unsur kelurahan yang terdiri dari tiga pilar yakni lurah, babinsa ( unsur dari koramil) serta babinkamtibmas (unsur dari polsek). Setelah melalui proses rapat beberapa kali serta diskusi di antara unsur pemerintahan, dan warga, maka pada 2016 disepakati dan diresmikan terbentuknya Forum Keamanan Terpadu. Meskipun lembaga ini tidak memiliki jatah pendanaan dari APBD, tetapi sebagai bentuk dukungan, pimpinan kelurahan (lurah) mengeluarkan SK yang memperkuat keberadaan forum tersebut sebagai lembaga/organisasi masyarakat yang didukung penuh oleh seluruh elemen masyarakat.

\section{Pengorganisasian yang dilakukan pimpina desa (Lurah dan Aparatnya) dalam melaksanakan Forum Keamanan Terpadu.}

Yakni pengelompokan kegiatan kerja yang konkret dan tegas sesuai dengan lingkup pekerjaan dan pembagian tugas. Meski FKT adalah lembaga bentukan warga, tetapi di dalam pelaksanaannya dibuat dengan sungguh-sungguh merangkul semua elemen masyarakat, sehingga dalam pelaksanaannya menjadi terintegrasi dan saling mendukung. /untuk memudahkan pengorganisasian peran dari masing-masing elemen masyarakat yang tergabung di FKT, maka lembaga ini membuat struktur organisasinya. 
PERSRESS

Volume 1 Nomor 1. Juli - Desember 2018

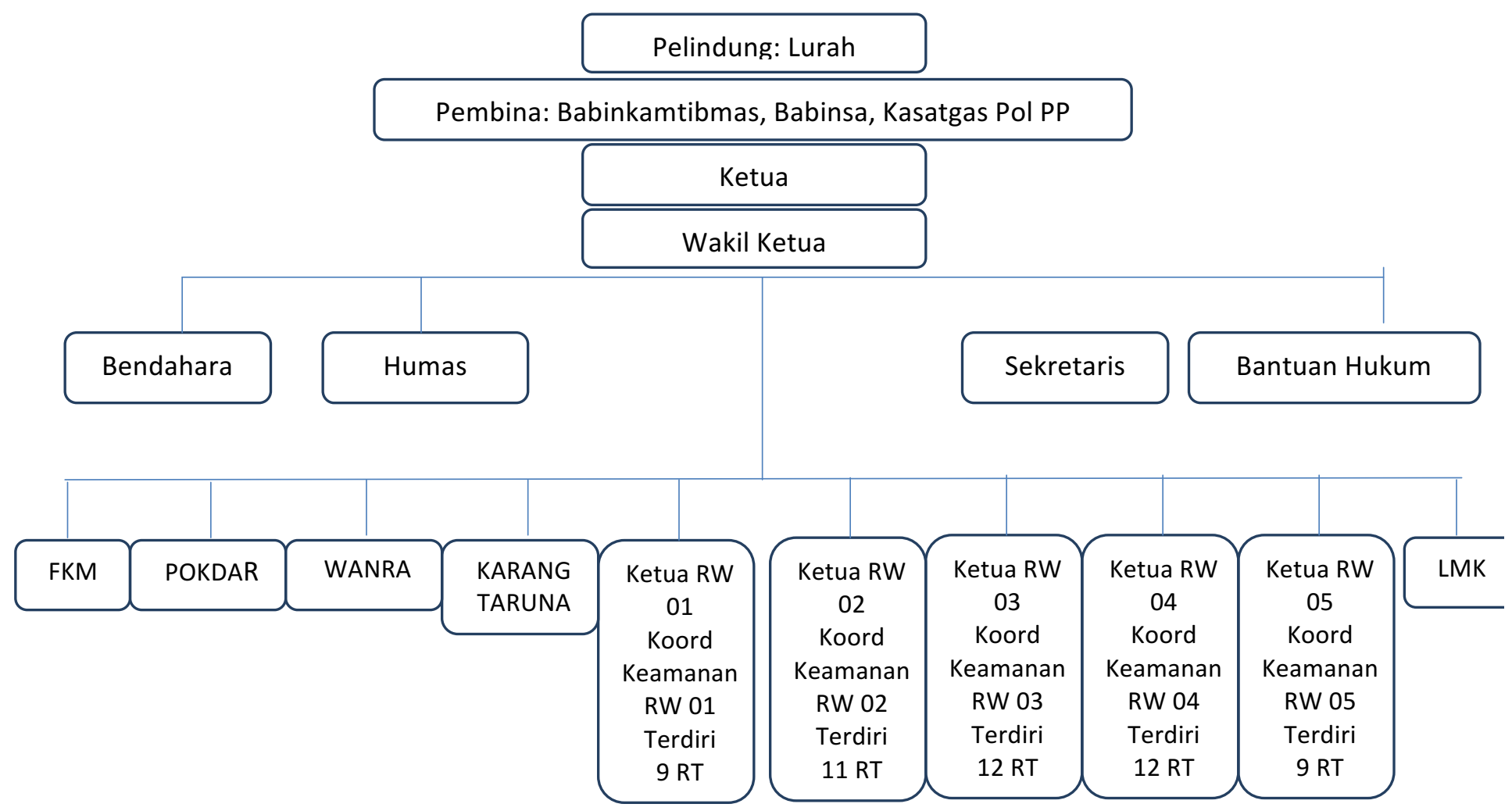

Gbr 1. Struktur Organisasi Forum Keamanan Terpadu Kelurahan Balekambang

Jadi, FKT di Balekambang merupakan lembaga swadaya masyarakat yang dijadikan satu-satunya pintu untuk mengamankan lingkungan masyarakat. Sebagaimana terpapar dalam bagan strukturnya, FKT terdiri dari beberapa unsur yang membentuknya yakni RT, RW, Karang Taruna, LMK, Pokdar (Kelompok Sadar) dibawah koordinator Polsek, Wanra di bawah koordinator Babinkamtibmas.

Tujuan FKT ini adalah untuk mengoordinasikan serta mensinergikan seluruh komponen/elemen warga di dalam menjaga keamanan. Jadi tidak berjalan sendiri-sendiri. Semua elemen, perwakilannya ada di FKT. Jadi elemen-elemen ini melaporkan setiap kejadian yang meresahkan kepada ketua FKT. Misalnya di titik mana ada tawuran, geng motor, pencurian, narkoba atau tindakan kekerasaan lainnya yang mengganggu masyarakat, maka dilaporkan ke FKT.

\section{a. Pelaksanaan Forum Keamanan Terpadu.}

Adalah membangkitkan dan mendorong semua personel organisasi agar berusaha untuk mencapai tujuan dengan ikhlas serta serasi dengan perencanaan dan usaha pengorganisasian dari pihak pimpinan. Dalam pelaksanaan pencapaian tujuan FKT, di setiap RW yang dianggap rawan saat ini sudah dibentuk 


\section{PERSRESI}

pos-pos (sekretariat) yang diisi oleh Pokdar, Wanra. Lalu koordinasi dan laporan disampaikan melalui HP dan WA.

Lembaga ini pun melakukan pembinaan kepada anggotanya, yang dilakukan secara parsial (bertahap), misalnya ketika ada acara pimpinan FKT hadir di tengah-tengah anggota (elemen yg ada di FKT) untuk memberikan pengarahan. FKT mengarahkan kepada anggota untuk melakukan deteksi dini (pemantauan: apabila ada gejolak-gejolak, maka warga harus melaporkan ke FKT dan 3 pilar), cegah dini dan tangkal dini. Ketika melihat ada unsur kejahatan, tidak boleh main hakim sendiri. Begitu pula dalam penyelesaian masalah, ketika ada oknum kejahatan yang tertangkap, langkah awal yang diambil FKT adalah penyelesaian secara kekeluargaan. Tetapi apabila sudah menjadi Target Operasi (TO), maka langsung melaporkan oknum tersebut ke pihak yang berwenang seperti ke Polsek. Sebagai gambaran kriminal yang sering terjadi di Balekambang hanya baru sebatas kriminal sosial saja.

Lalu setiap dua minggu sekali selalu ada pertemuan. Biasanya di malam minggu (jam 12 malam ke atas) menjelang patroli, memonitor dan menyisir wilayah untuk membubarkan gerombolangerombolan geng motor yang kerapkali muncul di wilayah Balekambang. FKT akan mempersuasi genggeng motor untuk membubarkan diri. Banyak warga yang turut berpartisipasi, sehingga kita membaginya ke dalam beberapa kelompok. "Sebelum berangkat, biasanya diberikan pegarahan dulu oleh saya selaku lurah, Babinsa, Binmas dan FKT,” ujar Mintarsih.

Perlu diketahui juga bahwa Forum Keamanan Terpadu ini merupakan pilot project sistem pengamanan warga yang ada di Jakarta Timur. Menurut Mintarsih, keberadaan FKT di Balekambang sempat membuat Walikota Jaktim datang ingin membuktikan di awal tahun 2017, "dan pada ssat itu seluruh anggota FKT dengan seragamnya masing-masing datang. Lalu Pak Walikota pun memberikan arahan".

Keberadaan FKT juga membantu kelurahan untuk siap siaga membantu keamanan yang diharapkan oleh pihak kecamatan. Jadi ketika camat meminta kepada saya untuk pengerahan warga menjaga keamanan, saya tinggal kontak FKT saja. Jadi nanti FKT yang menyediakan wanranya berapa orang, pokdarnya berapa orang. Pengendalian dan pengawasan terbantu oleh anggota FKT yang setiap malam men-share berbagai informasi kondisi di titik-titik poskonya. Sekalipun situasi dan kondisi aman, tetap mereka laporkan. Mereka bergadannya bergantian. Selain itu ada rapat khusus sebulan sekali di minggu kedua.

Menurut informan lain (Rofik, Ketua FKT), dalam melaksanakan tugas pengamanannya, FKT rutin melakukan pelaporan kepada lurah. Berikut penuturannya:

"Setiap jam 12 malam ke atas ada apel jaring atau komunikasi. Setiap hansip yang ada di wilayah kita harus melakukan komunikasi melalui HT, yakni melaporkan hal-hal yang sekiranya menonjol di 


\section{PERSRESI}

lingkungan kita, baik melalui WA, HT atau telfon. Termasuk kepada tiga pilarnya, yakni Lurah, Babinsa dan Babinkamtibmas"

Lalu sebagai bentuk transparansi info serta dorongan partisipasi kepada seluruh anggotanya, ketua FKT selalu melakukan Komunikasi terhadap para anggota. Rofik menjelaskan alur komunikasi di FKT yang dibangunya sebagai berikut,:

"Di lingkungan kita (FKT) kan ada LMK (lembaga musyawarah Kelurahan). LMK ini ada di setiap RW, dan ini menjadi pengurus FKT yang merupaka representasi warga. Lalu di RW juga ada Koordinator keamanan RW yang setiap malam bersinergi untuk memantau keamanan di lingkungan RW nya. Elemen berikutnya ada Pokdar, Wanra, Karang Taruna, termasuk Forkabi. Mereka semua bekerjasama secara sosial. Oleh karena itu bahasa saya kepada mereka bukan perintah, tetapi bahasa "minta tolong". Jadi menggunakan bahasa sosial untuk menyentuh hatinya. Kami, FKT tetap mengawal. Dengan demikian seluruh elemen warga akan bangkit dan bersinergi bersama untuk mengawal keamaan warga."

Bentuk pengamanan terpadu lainnya yang dilakukan di kelurahan yang memiliki 5 RW dan 53 RT ini adalah seperti yang dilakukan oleh Babinsa (salah satu pilar di wilayah kelurahan yang berasal dari unsur militer). Babinsa selalu menggunakan komunikasi sosial kepada masyarakat. Contohnya ketika terjadi bencana-bencana, Babinsa akan menggerakkan anggotanya dan menjalankan fungsinya untuk membantu dan mengamankan warganya.

"Anggota Babinsa di setiap keluarahan ada 2 orang. Kami disini bermitra denga wanra (rakyat terlatih). Wanra ini sudah dilatih dasar-dasar kemiliteran, seperti PBB, lalu penanganan dini terhadap bencana. Babinsa juga mengadakan LDK untuk karang taruna, latihan kedisiplinan, baris berbaris, penghormatan. Tempatnya di puncak, dan dananya swadaya dari masyarakat,“ ujar Informan 2, pimpinan Babinsa di Kelurahan Balekambang.

\section{b. Pengawasan yang dilakukan pimpinan desa dalam melaksanakan Forum Keamanan Terpadu.}

Adalah proses penetapan ukuran kinerja dan pengambilan tindakan untuk mendukung tercapainya tujuan organisasi. Tujuan pengawasan adalah menghindari penyelewegan atau penyimpangan atas tujuan yang hendak dicapai. Adapun Bentuk evaluasi kelurahan terhadap FKT adalah dengan melihat indikasiindikasi keberhasilan tugas FKT sebagai pengaman lingkungan.

1. Mendeteksi keadaan di sekitar lingkungan. Sudah satu (1) tahun ini (di tahun 2017) tidak ada tawuran baik antar warga maupun antara warga Balekambang dengan warga kelurahan lain. Ini bentuk kesungguhan FKT di dalam menertibkan lingkungan dan mewujudkan harmonisasi dalam bermasyarakat.

2. Mengidentifikasi anggota-anggota mana yang aktif dan mana yang tidak aktif. Sebagaimana diketahui bahwa anggota FKT ini merupakan perwakilan dari dari berbagai elemen masyarakat (RT, RW, Karang Taruna, LMK, Pokdar (Kelompok Sadar) dan Wanra). Ternyata tidak semua RT/RW aktif di 


\section{PERSESPS}

dalam kegiatan FKT. Padahal RT \& RW diberi anggaran oleh pemerintah masing-masing 1,5 juta dan 2 juta untuk kegiatan masyarakat. Lembaga lain yang juga mendapat anggaran adalah FKDM (Forum Kewaspadaan Dini Masyarakat), LMK (Lembaga Musyawarah Kelurahan) masing-masing 1,5 juta. Jadi seharusnya RT, RW LMK serta FKDM memberi kontribusi yang aktif terhadap lingkungan sekitar. Justru sebaiknya FKT sendiri dan anggota FKT seperti Karang Taruna, Pokdar dan Wanra tidak diberikan anggaran tetapi partisipasinya tinggi.

Sebagai informasi bahwa Karang Taruna untuk mendapatkan dana harus sedikit"berjuang" terlebih dulu, yakni membuat proposal. Biasanya proposal mereka diarahkan ke bagian sosial walikota. "Pernah satu kali karang taruna mendapat bantuan sebesar 3juta. Mereka gunakan untuk membuat nugget dari ikan terus dijual kembali ke bagian sosial di walikota. Karena di bagian sosial itu kan ada program bantuan non tunai ke masyarakat miskin, nah salah satu produk yang diberikan ke warga adalah nugget tersebut. Jadi itu bentuk kerjasamanya,“ menurut Mintarsih.

Dalam proses perencanaan, pilar utama desa, terutama pimpinan kelurahan menunjukkan sikap yang sangat kooperatif, merangkul aspirasi warganya bahkan memberikan dukungan yang kuat. Demokratisasi pun ditunjukkan oleh pimpinan kelurahan dengan menggelar pertemuan serta diskusi bersama warganya untuk mematangkan pendirian FKT. Jika dilihat dari perspektif teori likert dalam komunikasi organisasi, pimpinan Kelurahan Balekambang sangat adaptif terhadap situasi lingkungan setempat. Tentu saja persetujuan didirikannya Forum Keamanan Terpadu ini merupakan bagian dari upaya pimpinan mengakomodasi gagasan warga. Dalam pandangan teori ini, gaya kepemimpinan Lurah Balekambang lebih menunjukkan gaya konsultatif dan partisipatif.

Bentuk partisipasi lurah dalam pelaksanaan Forum Keamanan Terpadu ini bisa dilihat mulai dari keterlibatannya di awal pembentukan sampai upaya evaluasi lembaga, kinerja anggota dan pencapaiannya. Partisipatif adalah komunikasi yang terjadi pun lebih cair dengan alur atasan ke bawahan, bawahan ke atasan maupun bawahan ke bawahan. Pemimpin juga memberikan motivasi kepada pegawai dengan memberikan ruang bagi mereka berpartisipasi aktif dalam mewujudkan target organisasi. Proses komunikasi dan pertukaran ide berlangsung terbuka dari atasan ke bawahan maupun sebaliknya.

Hal ini terlihat dari membaurnya sosok lurah di dalam setiap kegiatan yang dilakukan FKT, mulai dari rapat bersama baik secara formal maupun informal, senantiasa hadir memberi motivasi kepada seluruh anggota FKT ketika akan melakukan penyisiran wilayah rawan di sekitar Balekambang. Bahkan tidak segan lurah pun turut bersinergi melakukan monitoring bersama dengan warganya, sekalipun harus dilakukan di jam 12 malam ke atas. Bentuk lain dari upaya pengayoman dan partisipatif dilakukan oleh pimpinan dengan menjadi pelindung FKT dan terlibat dalam pelaksanaan pengamanan lingkungan secara praktis. 


\section{PERSERESSI}

Sementara gaya kepemimpinannya yang bersifat konsultatif terlihat dari upaya lurah di dalam mengolaborasi dan mensinergikan berbagai elemen warga (Wanra, Pokdar, FKM, Karang Taruna serta RW) dalam satu lembaga keamanan bersama. Selain itu upaya kontroling pun terlihat pada kegiatan evaluasi yang dilakukan lurah kepada FKT, anggota dan capaiannya. Lurah tidak lepas tangan begitu saja, tetapi tetap membuka saluran komunikasi dengan pimpinan FKT.

Dalam hal berkomunikasi pelaksanaan Forum Keamanan Terpadu (FKT) lurah pun tida rigid dan birokratis. Misalnya dalam upaya kontroling, lurah tidak perlu harus setiap saat turun ke lapangan, tetapi dia cukup mendapat laporan dari ketua FKT melalui saluran telefon atau WA pribadi maupun WA grup. Di sini komunikasi terlihat cair dan bersifat dua arah. Membaurnya pimpinan desa dalam setiap kegiatan FKT menunjukkan gaya komunikasi yang diadopsi adalah equalitarian style, yakni terbuka dan menjunjung persamaan, tidak membuat strata dan berjarak.

\section{SIMPULAN}

Dari hasil penelaahan data di lapangan dan pembahasan, dapat disimpulkan bahwa Manajemen Komunikasi Pemerintahan Desa (dalam hal ini pihak kelurahan) di Balekambang dalam melaksanakan Forum Keamanan Terpadu sudah cukup sistemik dan terintegrasi mulai dari proses perencanaan sampai dengan evaluasi, hanya saja ada beberapa catatan yang masih harus ditingkatkan oleh aparat desa, yakni:

Dalam proses evaluasi, harus ada upaya re-organisasi terhadap para anggota yang tidak aktif berpartisipasi dalam mengamankan dan menertibkan lingkungan. Di sini pola komunikasi yang harus dikembangkan adalah dengan cara demokratis dan melakukan himbauan yang persuasif. Pimpinan desa/kelurahan harus pro-aktif "menyapa” warganya agar partisipasi warga dalam membangun ketertiban lingkungan dapat ditingkatkan.

\section{REFERENSI}

Abidin, Yusuf Zainal. 2015. Manajemen Komunikasi; Filosofi, Konsep dan Aplikasi. Bandung: CV Pustaka Setia Shimp, Terence A. 2003. Periklanan, Promosi, Komunikasi Pemasaran terpadu. Jakarta: Erlangga

Basrowi dan Sukidin. 2002. Metode Penelitian Kualitatif: Perspektif Mikro. Surabaya: Insan Cendikia

Creswell, John W. 1994. Research Design Qualitative \& Quantitative Approaches. London: Sage Publications.

Masmuh, Abdullah. 2008. Komunikasi Organisasi dalam perspektif teori dan praktek. Malang: UPT Penerbitan Universitas Muhammadiyah Malang.

Muhammad, Arni. 2005. Komunikasi Organisasi. Jakarta: Bumi Aksara 


\section{PERSERESSI}

Volume 1 Nomor 1. Juli - Desember 2018

Newman, W. Laurence. 2003. Social Research Methods; Qualitative and Quantitative Approaches

Pace, R.Wayne \& Faules, Don Face. 2000. Komunikasi Organisasi; Strategi Meningkatkan Kinerja Perusahaan. Bandung: PT. Remaja Rosdakarya

Robbins, Stephen P \& Judge, Timothy A. 2007. Organizational Behavior. Pearson Prentice Hall Soedarsono, Dewi K.. 2009. Sistem Manajemen Komunikasi (Teori, Model, Dan Aplikasi). Bangung: Simbiosa Rekatama Media.

Tubbs, Stewart L. \& Moss, Sylvia. 2005. Human Communication; Konteks-Konteks Komunikasi. Bandung: Remaja Rosdakarya

\section{Website}

http://komunikasicarasaya.blogspot.com

www.plus.googleapis.com

properti.kompas.com/2018

www.vivanews.co.id

www.inionline.co.id

www.kriminologi.id/maret 2018

www.detik.com

\section{Lainnya:}

Peraturan Pemerintah Republik Indonesia Nomor 73 Tahun 2005 pasal 5 tentang kelurahan

\section{BIODATA}

Yayu Sriwartini Dosen tetap di Prodi Ilmu Komunikasi FISIP, Universitas Nasional, Jakarta. Saat ini menjabat sebagai Ketua Program Studi Ilmu Komunikasi Universitas Nasional Jakarta. 